\title{
PENINGKATAN AKTIVITAS BELAJAR DAN HASIL BELAJAR SISWA DENGAN METODE PROBLEM BASED LEARNING PADA SISWA KELAS VIIA MTS NEGERI DONOMULYO KULON PROGO TAHUN PELAJARAN 2012/2013
}

\author{
Widodo, Lusi Widayanti \\ Universitas Ahmad Dahlan \\ J1. Kapas 9 Semaki Yogyakarta \\ wied_uad@yahoo.co.id
}

\begin{abstract}
Hasil belajar siswa di MTs Donomulyo, Nanggulan, Kulonprogo masih rendah. Hal ini disebabkan oleh kurangnya partisipasi aktif dan keterlibatan siswa selama proses pembelajaran. Guru perlu menerapkan metode pembelajaran yang dapat mendorong keterlibatan siswa dalam pembelajaran. Metode problem based learning adalah salah satu metode yang dapat memenuhi harapan tersebut. Tujuan penelitian ini adalah untuk mengetahui apakah metode problem based learning (PBL) dapat meningkatkan aktivitas belajar dan hasil belajar siswa. Penelitian ini merupakan penelitian tindakan kelas (PTK) dengan subjek penelitian adalah siswa kelas VII A semester 1 MTs Donomulyo, Nanggulan, Kulonprogo Tahun $2012 / 2013$. Metode pengumpulan data yang diguanakan dalam penelitian ini adalah metode tes dan observasi. Data yang terkumpul dianalisis dengan analisis deskriptif kualitatif. Hasil penelitian menunjukkan bahwa ada peningkatan aktivitas siswa dan hasil belajar setelah menerima pembelajaran dengan metode PBL. Sehingga dapat disimpulkan bahwa dengan menggunakan metode pembelajaran berbasis masalah dapat meningkatkan kegiatan pembelajaran dan hasil belajar siswa.
\end{abstract}

Key words: problem based learning, aktivitas belajar, hasil belajar.

\section{PENDAHULUAN}

Pembelajaran [1] didesain untuk membelajarkan siswa, artinya siswa ditempatkan sebagai subjek belajar. Dengan kata lain, pembelajaran lebih berorientasi pada aktivitas siswa untuk memperoleh hasil belajar berupa perpaduan antara aspek kognitif, afektif, dan psikomotor secara proposional. Keaktifan siswa ada yang secara langsung dapat diamati dan ada yang tidak dapat diamamti secara langsung, seperti mengerjakan tugas, berdiskusi, dan mengumpulkan data. Kadar keaktifan siswa tidak hanya ditentukan oleh aktivitas fisik semata, tetapi juga oleh aktivitas nonfisik seperti mental, intelektual, dan emosional. Oleh sebab itu, aktif atau tidaknya siswa dalam belajar hanya siswa sendiri yang mengetahui secara pasti.

Proses pembelajaran Ilmu Pengetahuan Alam (IPA) [2] termasuk fisika mestinya menekankan pada pemberian pengalaman langsung kepada siswa sehingga siswa memperoleh pemahaman mendalam tentang alam sekitar dan prospek pengembangan lebih lanjut dapat menerapkannya di dalam kehidupan kehidupan sehari-hari. Pembelajaran IPA di sekolah seharusnya melibatkan aspek sikap, proses, produk, dan aplikasi, sehingga siswa dapat mengalami proses pembelajaran secara utuh, memahami fenomena alam melalui kegiatan pemecahan masalah, metode ilmiah, dan meniru kerja ilmuan dalam menemukan fakta baru. Kecenderungan pembelajaran IPA saat ini, siswa hanya mempelajari IPA sebagai produk, menghapalkan konsep, teori dan hukum, serta berorientasi pada hafalan. Akibatnya, sikap, proses, dan aplikasi tidak tersentuh dalam pembelajaran. Pengalaman belajar yang diperoleh di kelas tidak utuh dan tidak berorientasi tercapainya standar kompetensi dan kompetensi dasar. Pada pembelajaran ini suasana kelas cenderung teacher-centered, guru hanya menyampaikan IPA sebagai produk dan siswa menghapal informasi faktual. Fakta di lapangan menunjukan bahwa siswa cenderung malas berfikir secara mandiri.

Masalah utama dalam pembelajaran di MTs Negeri Donomulyo adalah masih rendahnya hasil belajar siswa. Hal ini tampak dari rata-rata hasil ulangan tengah semester fisika kelas VII yang belum memenuhi nilai standar KKM. Kriteria Ketuntasan Minimal (KKM) yang telah ditetapkan oleh sekolah yaitu sebesar 70. Hasil ulangan tengah semester kelas VII A sebanyak 19 siswa dari 23 siswa masih mendapat nilai di bawah kriteria ketuntasan minimal (KKM). Pada materi wujud zat dan perubahan zat sebanyak 70,58\% siswa belum memenuhi KKM.

Berdasarkan wawancara yang dilakukan oleh penulis pada 16 Okober 2012 pukul 10.00 WIB dengan Sri Purwaningsih, S.Pd guru mata pelajaran fisika kelas VII MTs Negeri Donomulyo, Nanggulan, Kulon Progo rendahnya hasil belajar siswa diduga disebabkan antara lain karena: (1) rendahnya pemahaman siswa dalam menerima pelajaran yang diberikan oleh guru, sehingga sulit menjawab pertanyaan-pertanyaan; (2) belum terjadi suasana aktif dalam diskusi, dan (3) kurangnya keterlibatan siswa secara langsung. Beberapa siswa menjawab pertanyaan dengan ragu-ragu, keberanian siswa untuk mengajukan pendapat dan bertanya juga kurang. Guru juga lebih sering mengajar dengan metode ceramah. Selain itu, kurangnya fasilitas laboratorium yang menyebabkan jarang melakukan kegiatan praktikum. Karena jarangnya kegiatan praktikum maka guru hanya mengevaluasi pada aspek kognitif.

Melihat kondisi di atas proses pembelajaran di MTs Negeri Donomulyo, Nanggulan, Kulon Progo aktivitas belajarnya masih rendah, sehingga hasil belajar siswa rendah. Untuk mengatasi masalah tersebut perlu adanya 
inovasi metode belajar yang dapat meningkatkan aktivitas belajar siswa. Dengan adanya aktivitas yang tinggi diharapkan dapat meningkatkan hasil belajar siswa.

Untuk meningkatkan aktivitas belajar dan hasil belajar siswa dibutuhkan suatu pembelajaran yang efektif. Salah satu caranya yaitu dengan menggunakan metode problem based learning yakni metode pembelajaran yang berbasis teori belajar konstruktivistik yang dikenalkan oleh John Dewey. Secara umum pembelajaran berdasarkan masalah terdiri dari menyajikan kepada siswa situasi masalah yang otentik dan bermakna yang dapat memberikan kemudahan kepada mereka untuk melakukan penyelidikan dan inkuiri [3].

Kegiatan belajar memecahkan masalah merupakan usaha untuk mengembangkan kemampuan berpikir siswa. Berpikir adalah aktivitas kognitif tingkat tinggi yang melibatkan asimilasi dan akomodasi berbagai pengetahuan dan struktur kognitif yang dimiliki siswa untuk memecahkan suatu masalah [4].

Dalam metode problem based learning, pembelajaran fokus pada masalah yang dipilih sehingga siswa tidak hanya mempelajari konsep-konsep yang berhubungan dengan masalah tetapi juga metode ilmiah dalam memecahkan masalah tersebut. Tujuannya untuk memperoleh kemampuan dan kecakapan kognitif dalam memecahkan masalah secara rasional, lugas, dan tuntas. Oleh sebab itu, siswa tidak hanya memahami konsep yang relevan dengan masalah yang menjadi pusat perhatian tetapi juga memperoleh pengalaman belajar yang berhubungan dengan keterampilan menerapkan metode ilmiah dalam pemecahan masalah dan menumbuhkan pola berfikir kritis[2]. Dalam hal ini, hampir semua bidang studi dapat menggunakan metode problem based learning. Sehingga guru IPA sangat dianjurkan untuk menggunakan model dan strategi mengajar yang berorientasi pada cara pemecahan masalah [5].

Selain memiliki keunggulan, metode problem based learning juga memiliki kelemahan, antara lain ketika siswa merasa bahwa masalah akan sulit untuk dipecahkan maka siswa akan merasa enggan untuk mencoba. Tanpa pemahaman mengapa mereka berusaha untuk memecahkan masalah yang sedang dipelajari, maka mereka tidak akan belajar apa yang akan mereka pelajari, serta membutuhkan waktu cukup lama untuk persiapan [1].

Berdasarkan keunggulan yang dimiliki metode problem based learning, maka metode ini dapat dijadikan sebagai salah satu alternatif tindakan untuk meningkatkan aktivitas belajar dan hasil belajar siswa. Meskipun metode problem based learning memiliki kekurangan, tetapi hal tersebut hanya berdampak sangat kecil dalam meningkatkan aktivitas belajar dan hasil belajar siswa. Oleh karena itu, tindakan yang diberikan pada kelas yang akan ditingkatkan aktivitas belajar dan hasil belajarnya adalah berupa penerapan metode problem based learning.

Penelitian yang dilakukan oleh [6] yang berjudul "Peningkatan Aktivitas dan Hasil Belajar Siswa melalui Model Pembelajaran Problem Based Learning" pada mata pelajaran kewirausahaan menyimpulkan bahwa Model
Problem Based Learning dapat meningkatkan aktivitas dan hasil belajar siswa.

Berdasarkan uraian di atas, maka peneliti telah melakukan penelitian tentang bagaimana upaya peningkatkan hasil belajar fisika dengan metode problem based learning pada siswa kelas VII semester I MTs Negeri Donomulyo, Nanggulan, Kulon Progo Tahun Pelajaran 2012/2013 pokok bahasan wujud zat dan perubahannya.

Tujuan penelitian ini adalah:

1. Untuk mengetahui apakah metode problem based learning dapat meningkatkan aktivitas belajar siswa kelas VIIA semester I MTs Negeri Donomulyo, Nanggulan, Kulon Progo Tahun Pelajaran 2012/2013 pada pokok bahasan wujud zat dan perubahannya.

2. Untuk mengetahui apakah metode problem based learning dapat meningkatkan hasil belajar siswa kelas VIIA semester I MTs Negeri Donomulyo, Nanggulan, Kulon Progo Tahun Pelajaran 2012/2013 pada pokok bahasan wujud zat dan perubahannya.

\section{LANDASAN TEORI}

\section{a. Problem Based Learning}

Salah satu metode pembelajaran yang diharapkan dapat meningkatkan keaktifan siswa adalah metode problem based learning. Metode ini mempersiapkan siswa untuk berpikir kritis dan analitis, untuk mencari serta menggunakan sumber pembelajaran yang sesuai (Amir, 2010 : 21). Dalam metode problem based learning, sebelum pelajaran dimulai, siswa diberikan masalahmasalah. Masalah yang disajikan adalah masalah yang memiliki konteks dengan dunia nyata, semakin dekat dengan dunia nyata, maka akan semakin baik pengaruhnya pada peningkatan kecakapan pada siswa. Dari masalah yang diberikan ini siswa kemudian bekerjasama dalam kelompok, mencoba memecahkan masalah dengan kemampuan yang dimiliki, dan sekaligus mencari informasi-informasi baru yang relevan. Disini peran guru adalah sebagai fasilitator yang mengarahkan siswa dalam mencari dan menemukan solusi dan sekaligus menentukan kriteria pencapaian proses pembelajarannya [7].

Proses utama dalam problem based learning terletak pada diri siswa. Variabel dari luar hanya intruksi yang membantu atau membimbing siswa dalam menyelesaikan masalah. Hasil belajar yang diperoleh sukar dilupakan dan dapat dimanfaatkan pada berbagai situasi yang termasuk dalam kategori tertentu. Kemampuan memecahkan masalah merupakan hasil belajar yang sangat penting dan harus dikuasai oleh siswa disamping hasil belajar pada aspek kognitif [8].

Problem based learning dikembangkan untuk membantu siswa mengembangkan kemampuan berpikir, mengatasi masalah, keterampilan penyelidikan, kemampuan mempelajari peran sebagai orang dewasa melalui keterlibatan mereka dalam pengalaman nyata atau simulasi, dan menjadi pembelajar yang mandiri dan independen [44.

Problem based learning lebih dari sekedar lingkungan yang efektif untuk pengetahuan tertentu. Pengetahuan riil bagi para siswa adalah sesuatu yang dibangun atau 
ditemukan oleh siswa itu sendiri. Jadi pengetahuan bukanlah seperangkat fakta, konsep atau kaidah yang diingat siswa, tetapi harus merekonstruksi pengetahuan itu kemudian memberi makna melalui pengalaman nyata. Dalam pemeblajaran ini siswa harus dilatih untuk memecahkan masalah, menemukan sesuatu yang berguna bagi dirinya dan bergulat dengan ide-ide dan kemudian mampu merekonstruksinya [9].

Dari beberapa metode mengajar yang ada, metode problem based learning lebih banyak memiliki keunggulan, baik dari segi sifat materi, tujuan, serta kemampuan yang dapat dimiliki siswa [5].

\section{b. Hasil belajar}

Menurut Suprijono (2012:5), hasil belajar adalah polapola perbuatan, nilai-nilai, pengertian-pengertian, sikapsikap, apresiasi dan keterampilan. Selanjutnya Supratiknya (2012 : 5) mengemukakan bahwa hasil belajar yang menjadi objek penilaian kelas berupa kemampuan-kemampuan baru yang diperoleh siswa setelah mereka mengikuti proses belajar-mengajar tentang mata pelajaran tertentu. Dalam sistem pendidikan nasional rumusan tujuan pendidikan mengacu pada klasifikasi hasil belajar dari Bloom yang secara garis besar yaitu aspek kognitif, aspek afektif dan aspek psikomotor.

\section{c. Aktivitas belajar}

Berbuat untuk merubah tingkah laku melalui perbuatan adalah prinsip belajar. Ada atau tidaknya belajar dicerminkan dari ada atau tidaknya aktivitas. Tanpa ada aktivitas, belajar tidak mungkin terjadi. Sehingga dalam interaksi belajar-mengajar aktivitas merupakan prinsip yang penting [9].

Penggunaan metode, pendekatan belajar mengajar dan orientasi belajar menyebabkan aktivitas belajar setiap siswa berbeda-beda. Ketidaksamaan aktivitas belajar siswa melahirkan kadar aktivitas belajar yang bergerak dari aktivitas belajar yang rendah sampai aktivitas belajar yang tinggi [11].

\section{METODE PENELITIAN}

Jenis penelitian adalah penelitian tindakan kelas (Classroom Action Research). Penelitian tindakan kelas adalah penelitian tindakan yang bersifat reflektif dan kolaboratif dan dilakukan dengan tujuan untuk memperbaiki mutu praktek pembelajaran di kelas [12].

Penelitian tindakan kelas ini terdiri dari empat tahapan, yakni (1) perencanaan, (2) pelaksanaan, (3) pengamatan, dan (4) refleksi. Setelah melakukan tindakan refleksi yang mencakup analisis, sintesis dan penilaian terhadap hasil pengamatan proses dan hasil tindakan yang dilakukan, biasanya timbul permasalahan atau pemikiran yang perlu mendapat perbaikan, sehingga perlu dilakukan perencanaan ulang, tindakan ulang, pengamatan ulang, serta refleksi ulang. Tahap-tahap kegiatan ini terus berlangsung sampai suatu permasalahan dianggap selesai [13].

Subjek penelitian adalah siswa kelas VIIA yang MTs Negeri Donomulyo, Nanggulan, Kulon Progo semester 1 tahun pelajaran 2012/2013. Sedangkan objek dalam penelitian ini adalah metode problem based learning untuk meningkatkan aktivitas belajar dan hasil belajar pada pokok bahasan wujud zat dan perubahannya.

Teknik pengumpulan data dalam penelitian ini adalah tes dan observasi. Tes merupakan instrumen pengumpulan data untuk mengukur pengetahuan siswa pada aspek kognitif mengenai mata pelajaran fisika. Dalam penelitian ini instrumen yang digunakan adalah tes tertulis dalam bentuk pretest dan posttest (soal pretest sama dengan soal posttest). Tes tertulis dinyatakan dalam bentuk soal pilihan ganda dengan alternatif jawaban a, b, c, dan d dengan skor benar bernilai 1 dan salah bernilai 0 .

Observasi merupakan teknik pengumpulan data dengan cara mengamati setiap kejadian yang sedang berlangsung dan mencatatnya dengan alat observasi tentang hal-hal yang akan diteliti. Observasi dalam penelitian ini ditujukan untuk menilai kinerja siswa dan tingkat aktivitas siswa selama proses pembelajaran berlangsung dengan metode problem based learning. Observasi pada siswa dilakukan untuk mengamati aktivitas belajar siswa, aspek afektif, dan aspek psikomotor yang digunakan untuk memperoleh data kinerja siswa selama kegiatan belajar mengajar. Format dari penilaian ini berupa rating scale yang dibuat dalam bentuk checklist. Jadi dalam pengisian penilaian kinerja siswa, observer hanya memberikan tanda checklist $(\sqrt{ })$ pada kolom yang sesuai selama proses pembelajaran berlangsung.

Data yang diperoleh dianalisis secara deskriptif kualitatif yaitu menyajikan data dalam bentuk uraian serta pembahasan berdasarkan hasil penelitian.

Data nilai tes (pretest dan posttest) digunakan untuk mengukur hasil belajar dari aspek kognitif, maka dilakukan analisis terhadap butir soal [3] dengan rumus :

$$
\mathrm{KB}=\frac{T}{T_{t}} \times 100 \%
$$

(1)

Keterangan:

$K B=$ ketuntasan belajar

$T \quad=$ jumlah skor yang diperoleh siswa

$T_{t} \quad=$ jumlah skor total

Rumus untuk mengetahui aktivitas belajar siswa, aspek afektif dan aspek psikomotor sebagai berikut [14]:

$$
N P=\frac{R}{S M} \times 100
$$

(2)

\section{Keterangan:}

$N P=$ nilai persen yang diharapkan

$R=$ skor mentah yang diperoleh siswa

$S M=$ kor maksimal tes

Dengan kriteria:

$86 \%-100 \%=$ sangat baik

$76 \%-85 \%=$ baik

$60 \%-75 \%=$ cukup

$55 \%-59 \%=$ kurang

$$
\leq \quad 54 \% \quad=\text { sangat kurang }
$$




\section{HASIL DAN PEMBAHASAN}

Hasil penelitian dari siklus I, II, dan III menunjukkan adanya peningkatan aktivitas belajar siswa dan hasil belajar baik dari aspek kognitif, afektif, maupun psikomotor. Hal ini dapat dilihat pada tabel 1 .

Tabel 1. Persentase pada setiap aspek yang dinilai

\begin{tabular}{lcccc}
\hline Aspek yang dinilai & Silus 1 & Siklus 2 & Siklus 3 \\
\hline Aktivitas belajar & & $70,36 \%$ & 81,42 & $\%$ \\
$94,47 \%$ & & & 88,41 & $\%$ \\
Aspek afektif & $78,99 \%$ & & & \\
$97,10 \%$ & & & & \\
Aspek psikomotor & $74,25 \%$ & $85,40 \%$ & $92,93 \%$ \\
Aspek kognitif & & $73,91 \%$ & $86,96 \%$ & $\%$ \\
$91,30 \%$ & & & &
\end{tabular}

Dari tabel di atas terlihat bahwa pada siklus I ketuntasan belajar klasikal posttest belum tercapai yaitu $\leq 85 \%$, siklus II dan siklus III sudah memenuhi kriteria ketuntasan belajar klasikal pretest dan posttest yaitu $\geq 85 \%$.

Meningkatnya aktivitas belajar siswa juga diiringi peningkatan hasil belajar baik dari aspek kognitif, afektif maupun psikomotor sehingga tak perlu dilanjutkan ke siklus berikutnya.

\section{KESIMPULAN}

Berdasarkan hasil penelitian di MTs Negeri Donomulyo, Nanggulan, Kulon Progo dapat disimpulkan sebagai berikut: (a) Metode problem based learning dapat meningkatkan aktivitas belajar siswa kelas VIIA di MTs Donomulyo, Nanggulan, Kulon Progo pada pokok bahasan wujud zat dan perubahannya. (b) Metode problem based learning dapat meningkatkan hasil belajar siswa kelas VIIA di MTs Donomulyo, Nanggulan, Kulon Progo pada pokok bahasan wujud zat dan perubahannya.

\section{UCAPAN TERIMA KASIH}

Ucapan terima kasih penulis sampaikan kepada Rektor Universitas Ahmad Dahlan yang telah membiayai penulisan artikel dan keikutsertaan dalam forum seminar ini.

\section{PUSTAKA}

Artikel jurnal:

[6] Fadly, Aditiya. 2012. "Peningkatan Aktivitas dan Hasil Belajar Siswa melalui Model Pembelajaran Problem Based Learning (PBL)". Jurnal. http://fe.um.ac.id/wpcontent/uploads/2012/08/JURNAL1 .pdf. diunduh 27 Desember, 2012.pp 1-1

Buku:

[1] Sanjaya, Wina. 2012. Strategi Pembelajaran Berorientasi Standar Proses Pendidikan. Jakarta : Kencana Prenada Media Group.

[2] Trianto. 2010. Model Pembelajaran Terpadu. Jakarta : Bumi Aksara.

[3] Trianto. 2011. Mendesain Model Pembelajaran Inovatif-Progresif. Jakarta : Kencana Prenada Media Group.

[4] Suprijono, Agus. 2012. Cooperative Learning : Teori dan Aplikasi PAIKEM. Yogyakarta : Pustaka Pelajar.

[5] Syah, Muhibbin. 2010. Psikologi Pendidikan dengan Pendekatan Baru. Bandung: Remaja Rosdakarya.

[7] Amir, M.Taufiq. 2010. Inovasi Pendidikan Melalui Problem Based Learning. Jakarta : Kencana Prenada Media Group.

[8] Nasution. 2011. Berbagai Pendekatan dalam Proses Belajar dan Mengajar. Jakarta : Bumi Aksara.

[9] Sardiman, A.M. 2011. Interaksi dan Motivasi Belajar Mengajar. Jakarta: Raja Grafindo Persada.

[10] Supratiknya, A. 2012. Penialian Hasil Belajar dengan Teknik Nontes. Yogyakarta : Universitas Sanata Darma.

[11] Djamarah, Syaiful Bahri. 2010. Guru dan Anak Didik dalam Interaksi Edukatif. Jakarta : Rineka Cipta.

[12] Arikunto, S., Suhardjono, dan Supardi. 2008. Penelitian Tindakan Kelas. Jakarta: Bumi Aksara.

[13] Muslich, Masnur. 2010. Melaksanakan PTK Itu Mudah. Jakarta : Bumi Aksara.

[14] Purwanto, Ngalim. 2006. Prinsip-Prinsip dan Teknik Evaluasi Pengajaran. Bandung: PT Remaja Rosdakarya. 